\title{
Host range, symptom expression and RNA 3 sequence analyses of six Australian strains of Cucumber mosaic virus
}

\author{
Emy Sulistyowati ${ }^{\mathrm{A}, \mathrm{B}, \mathrm{C}, \mathrm{G}}$, Neena Mitter ${ }^{\mathrm{A}, \mathrm{G}}$, Shanna Bastiaan-Net ${ }^{\mathrm{A}, \mathrm{D}}$, \\ Marilyn J. Roossinck ${ }^{\mathrm{E}}$ and Ralf G. Dietzgen ${ }^{\mathrm{A}, \mathrm{B}, \mathrm{F}}$ \\ ${ }^{A}$ Department of Primary Industries and Fisheries, Queensland Agricultural Biotechnology Centre, \\ Queensland Bioscience Precinct, 306 Carmody Road, St Lucia, Qld 4067, Australia. \\ ${ }^{\mathrm{B}}$ The University of Queensland, Department of Microbiology and Parasitology, \\ School of Molecular and Microbial Sciences, St Lucia, Qld 4072, Australia. \\ ${ }^{C}$ Present address: Research Institute for Tobacco and Fibre Crops, PO Box 199, Malang, Indonesia 65152. \\ DPresent address: Department of Molecular Plant Physiology, Utrecht University, 3584 CH Utrecht, The Netherlands. \\ ${ }^{\mathrm{E}}$ The S.R. Noble Foundation, PO Box 2180, Ardmore OK 73402, USA. \\ ${ }^{\mathrm{F}}$ Corresponding author. Email: ralf.dietzgen@dpi.qld.gov.au \\ ${ }^{\mathrm{G}}$ The first two authors contributed equally to this work.
}

\begin{abstract}
We have characterised six Australian Cucumber mosaic virus (CMV) strains belonging to different subgroups, determined by the sequence of their complete RNA 3 and by their host range and the symptoms they cause on species in the Solanaceae, Cucurbitaceae and on sweet corn. These data allowed classification of strains into the known three CMV subgroups and identification of plant species able to differentiate the Australian strains by symptoms and host range. Western Australian strains 237 and Twa and Queensland strains 207 and 242 are closely related members of CMV subgroup IA, which cause similar severe symptoms on Nicotiana species. Strains 207 and 237 (subgroup IA) were the only strains tested which systemically infected sweet corn. Strain 243 caused the most severe symptoms of all strains on Nicotiana species, tomato and capsicum and appears to be the first confirmed subgroup IB strain reported in Australia. Based on pair-wise distance analysis and phylogeny of RNA 3, as well as mild disease symptoms on Nicotiana species, CMV 241 was assigned to subgroup II, as the previously described Q-CMV and LY-CMV.
\end{abstract}

Additional keywords: host differentials, phylogeny, reverse transcription-polymerase chain reaction, serogroup.

\section{Introduction}

Cucumber mosaic virus (CMV) is the type species of the genus Cucumovirus, family Bromoviridae. CMV has a worldwide distribution and is of economic importance in many crops. Significant features of CMV include broad host range of about 1200 monocotyledonous and dicotyledonous species and aphid transmissibility (Edwardson and Christie 1991; Palukaitis et al. 1992). CMV has a tripartite positivesense RNA genome. Proteins 1a, 2a and 3a are expressed from genomic RNAs 1, 2 and 3, respectively, whereas the coat protein $(\mathrm{CP})$ and $2 \mathrm{~b}$ protein are expressed from subgenomic RNA 4 and RNA 4A, respectively (Palukaitis et al. 1992; Ding et al. 1994).

CMV strains have been divided into two subgroups, I and II, based on symptomatology, serology and sequence homology (Palukaitis et al. 1992). Recently, subgroup I has been further divided into subgroups IA and IB based on sequence variation and phylogeny (Roossinck et al. 1999). CMV infection causes a broad spectrum of symptoms from mild to severe mosaic, stunting, filiformism, chlorosis and necrosis, depending on virus strain and host (Carrère et al. 1999). In tobacco, CMV strains belonging to subgroup I tend to cause severe mosaic whereas subgroup II strains lead to mild mosaic (Wahyuni et al. 1992; Zhang et al. 1994). Some subgroup I strains cause fern-shaped or filiform leaves in tomato (Hellwald et al. 2000b; Stamova and Chetelat 2000). Maize appears to be resistant to systemic infection by most subgroup II strains (Wahyuni et al. 1992; Carrère et al. 1999; Ryu et al. 1998). CMV sequences that control symptom type and virulence have been mapped to the $3 \mathrm{a}$ and $\mathrm{CP}$ genes on RNA 3 (Carrère et al. 1999; Suzuki et al. 1995; Sugiyama et al. 2000; Szilassy et al. 1999), but RNAs 1 and 2 have also 
been implicated (Roossinck and Palukaitis 1990; Zhang et al. 1994; Hellwald et al. 2000b; Soards et al. 2002).

Many Australian CMV strains have been collected over the years, but only some of them have been characterised, and to various degrees. Host range and symptomatology were used to characterise 14 Australian CMV strains and classify them into subgroups I or II by dot blot hybridisation of their RNAs (Wahyuni et al. 1992). A range of serological tests using poly- and monoclonal antibodies divided these strains (except Ly-CMV) into two serogroups that mirrored the RNA hybridisation-based subgroups. Subsequently, 22 Australian CMV strains were compared by dsRNA mobility assay, polymerase chain reaction - restriction enzyme analysis of the $\mathrm{CP}$ gene, dot blot hybridisation with subgroup-specific RNA 3 probes and serogrouping using monoclonal antibodies (Pares et al. 1998).

A search of international nucleotide sequence databases revealed that full-length RNA sequences are available for only two Australian strains, Q-CMV and Ly-CMV, both belonging to subgroup II (Davies and Symons 1988; Rezaian et al. 1984, 1985; Roossinck 2002), and little is known about their biological properties. More detailed biological and molecular characterisation and differentiation of additional CMV strains will provide a more complete picture of CMV in Australia. This may assist in the improvement of diagnostic tests and may provide the basis for the identification of potential determinants of CMV host range and virulence. This paper describes the characterisation of six Australian CMV strains by their experimental host range and full length RNA 3 sequences.

\section{Methods}

\section{Virus strains}

Six CMV strains were obtained from the Plant Virus Collection of the Department of Primary Industries and Fisheries, Queensland. CMV Twa was provided by Prof John Randles (University of Adelaide). The origins and sero-grouping of all strains are detailed in Table 1. Following field collection, the CMV strains had been indexed on selective host plants to assure biological purity (John Thomas, personal communication). Freeze-dried cultures were initially inoculated to cucumber and squash seedlings, then propagated and maintained in tobacco cultivar W38.

\section{Inoculation of plants and host range analysis}

Four independent host range experiments were carried out under glasshouse conditions. Sap inoculum was prepared by grinding systemic symptomatic leaves of infected tobacco plants in $10 \mathrm{~mm}$ sodium phosphate buffer, $\mathrm{pH} 7.4$ containing $1 \mathrm{~g} / \mathrm{L}$ sodium sulphite. Seedling test plants (4-5 leaf stage) were dusted with carborundum, rub-inoculated with the sap and rinsed with tap water. Except for cucurbits, which were inoculated on the cotyledons, the youngest two expanded leaves were inoculated. Symptoms were recorded at 3 weeks post-inoculation (wpi), when samples from young expanded leaves were collected for ELISA. Plant species used were cucumber (Cucumis sativus cv. Green Gem), zucchini (Cucurbita pepo cvv. Green Ruffles and Black Jack), tomato (Lycopersicon esculentum cv. Grosse Lisse), capsicum (Capsicum annuum cv. Yolo Wonder), tobacco (Nicotiana tabacum cvv. W38 and Xanthi), N. glutinosa, N. benthamiana, sweet corn (Zea mays cv. Jubilee), bean (Phaseolus vulgaris cv. Bountiful) and cowpea (Vigna unguiculata subsp. unguiculata cv. Black Eye).

\section{Detection of CMV by ELISA}

Double antibody sandwich ELISA (Clark and Adams 1977) was used to detect CMV in infected plants. CMV antisera and alkaline phosphatase conjugate (Sanofi, France) were diluted 200 -fold in coating buffer and phosphate-buffered saline containing $0.05 \%$ Tween 20 and $1 \%$ skim milk, respectively. Leaf samples were extracted in a buffer containing $0.5 \mathrm{M}$ citrate $\mathrm{pH} 8.0,0.5 \mathrm{~m}$ EDTA, $0.05 \%$ Tween 20 and $0.2 \%$ bovine serum albumin.

\section{Isolation and cloning of CMV RNA 3}

Virus particles from all Australian CMV strains under investigation were purified from $5 \mathrm{~g}$ of infected tobacco leaves and RNA extracted from purified virus preparations following the method of Roosinck and White (1998). Complementary DNA of RNA 3 was generated from the total viral RNA using Expand Reverse Transcriptase (Roche Diagnostics, Australia) following the manufacturer's instructions and CMV subgroup I- or II-specific RNA 3 primers RP3 (5'-AAGGAGACCACTGCAGGG-3') and SD6 (Ding et al. 1994). Full length RNA 3 was amplified by PCR using primer pairs FP1 (5'-GTAATCTTACCACTGTGTGTG-3') and RP3 for subgroup I strains and SD10 (Ding et al. 1994) and SD6 for subgroup II strains with 30 cycles of $94^{\circ} \mathrm{C}$ for $1 \mathrm{~min}, 50^{\circ} \mathrm{C}$ for $1 \mathrm{~min}$ and $72^{\circ} \mathrm{C}$ for $2 \mathrm{~min}$ in a thermal cycler. PCR products were analysed on a $1 \%$ agarose $/ 1$ $\times$ Tris-acetate-EDTA (TAE) gel, excised, purified using a QIAquick Gel Extraction Kit (Qiagen, Germany) and ligated into pCR2.1-TOPO vector (Invitrogen, Carlsbad, CA, USA) and cloned into Escherichia coli TOP10 cells following the manufacturer's protocol. Recombinant clones were selected on LB agar containing $50 \mathrm{mg} / \mathrm{L}$ of ampicillin and plasmids were purified using an UltraClean plasmid preparation kit (Mo Bio Laboratories, Solana Beach, CA, USA).

Table 1. List of Australian Cucumber mosaic virus strains used in this study

\begin{tabular}{lllccl}
\hline Strain & Original host & Location & Year & Sero-group & Reference \\
\hline 207 & Lycopersicon esculentum & Redland Bay, Qld & 1987 & I & Pares et al. (1998) \\
237 & Cucumis melo & Western Australia & 1985 & I & Unpublished \\
241 & Capsicum annuum & Queensland & 1986 & II & Unpublished \\
242 & Beta vulgaris subsp. cicla & Queensland & 1973 & I & Unpublished \\
243 & Passiflora edulis & Cairns, Qld & 1970 & I & Pares et al. $(1998)$ \\
$245^{\text {A }}$ & Capsicum annuum & Queensland & 1964 & II & Pares et al. $(1998)$ \\
Twa & Capsicum annuum & Western Australia & - & I & Wahyuni et al. (1992) \\
\hline
\end{tabular}

${ }^{\mathrm{A}} \mathrm{Q}-\mathrm{CMV}$ was derived from this strain. 
Table 2. Sizes of RNA 3, open reading frames (ORF), intergenic region (IGR) and GenBank accession numbers of Australian Cucumber mosaic virus strains

\begin{tabular}{|c|c|c|c|c|c|}
\hline \multirow[t]{2}{*}{ CMV strains } & \multirow[t]{2}{*}{ GenBank accession number } & \multicolumn{4}{|c|}{ Number of nucleotides } \\
\hline & & RNA 3 & 3a ORF & CP ORF & IGR \\
\hline 207 & $\mathrm{AJ} 585517^{\mathrm{A}}$ & 2204 & 840 & 657 & 297 \\
\hline 237 & AJ585518 & 2193 & 840 & 657 & 297 \\
\hline 241 & AJ $585519^{\mathrm{A}}$ & 2211 & 840 & 657 & 299 \\
\hline 242 & AJ585520 A & 2208 & 840 & 657 & 297 \\
\hline 243 & AJ585521 $1^{\mathrm{A}}$ & 2211 & 837 & 657 & 299 \\
\hline Twa & AJ $585522^{\mathrm{A}}$ & 2184 & 840 & 657 & 297 \\
\hline Q & M21464 & 2197 & 840 & 657 & 284 \\
\hline Ly & AF198103 & 2203 & 840 & 657 & 288 \\
\hline
\end{tabular}

${ }^{\mathrm{A}}$ Isolate sequences determined in this study.

\section{Nucleotide sequencing and phylogenetic analysis}

Plasmid DNA was sequenced using the ABI Prism BigDye Terminator Cycle Sequencing Ready Reaction mix (Applied Biosystems, Melbourne, Australia) and analysed through the Australian Genome Research Facility (Brisbane, Australia). Three RNA 3 clones of each CMV strain were fully sequenced on both strands. Sequences were edited and an RNA 3 consensus sequence of each strain was generated using Sequencher 3.1.1 software (Gene Codes Corporation, Ann Arbor, MI, USA).

A nucleotide sequence alignment of the full length RNA 3 and of the ORF 3a of all Australian CMV strains was done using CLUSTALW (Thompson et al. 1994) and pair-wise distances determined using HOMOLOGIES software networked through the Australian National Genome Information Service (ANGIS). For phylogeny estimations, full length RNA 3 sequences of all Australian CMV strains and of selected strains available on GenBank representing the three subgroups were aligned by using the GCG program PILEUP with the ER strain of Peanut stunt virus (ER-PSV) as an outgroup. Alignments were edited by eye for best fit using MacCLADE. Maximum-parsimony trees were derived using PAUP (version 4) and a bootstrap analysis done with either the heuristic (1000 replicates) or the branch-and-bound (100 replicates) search option. Gaps were handled as a fifth character state. Branches supported by bootstrap values of less than $70 \%$ were judged as inconclusive and were collapsed.
GenBank accession numbers of the reference CMV strains used are Fny (D10538), IA (AB042294), Ix (U20219), Leg (D16405), LS (AF127976), Mf (AJ276481), Nt9 (D28780), O (D00385), SD (AB008777), Tfn (Y16926), Trk7 (L15336), Y (D12499) and ER-PSV (U15730), whereas those for the Australian strains are detailed in Table 2.

\section{Results}

Virus purification and analysis of encapsidated RNAs

RNA extracted from purified virus particles of all six Australian CMV strains showed the presence of genomic RNAs 1, 2 and 3 and subgenomic RNA 4 (Fig. 1). No small RNA species of a size corresponding to that of satellite RNAs were detected in total encapsidated CMV RNA extracts from any of the strains (Fig. 1).

\section{Experimental host range and symptoms}

The Australian CMV strains could be differentiated by their symptomatology and/or their host range (Table 3). When comparing the four host range experiments, which were conducted at different times of the year under glasshouse conditions, symptoms were generally more severe during

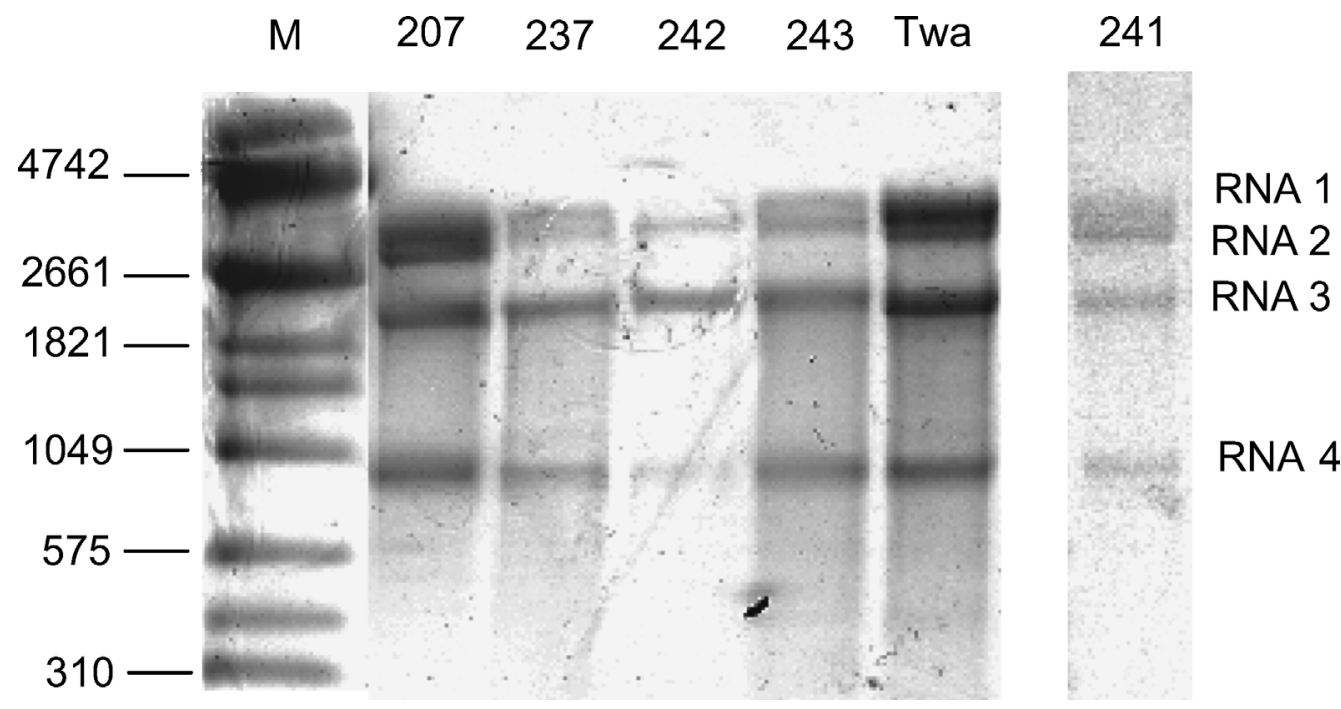

Fig. 1. Agarose gel electrophoresis of total RNA of purified preparations from six Australian Cucumber mosaic virus strains. M, RNA molecular weight (bases) markers (Roche, Castle Hill, NSW); RNAs 1 to 4 are indicated. 
Table 3. Differentiating systemic symptoms between Australian Cucumber mosaic virus strains on selected hosts

\begin{tabular}{lll}
\hline CMV strain & Host species & Differentiating symptoms \\
\hline 207 & Z. mays & Chlorotic streaks and spots along leaf edges \\
& N. glutinosa & Severe mosaic and leaf distortion \\
& C. annuum & Severe mosaic and leaf distortion \\
& Z. mays & Chlorotic streaks and spots along leaf edges \\
& N. glutinosa & Severe mosaic and leaf distortion \\
& L. esculentum & Severe mosaic and leaf down-curling \\
& N. benthamiana & Severe mosaic and leaf distortion; stunted growth \\
242 & L. esculentum & Severe mosaic and moderate spindle leaves \\
& N. benthamiana & Severe mosaic and leaf distortion; stunted growth \\
Twa & L. esculentum & Severe mosaic and severe fern-shaped leaves \\
243 & C. annuum & Severe mosaic and leaf distortion \\
& N. glutinosa & Severe mosaic and leaf distortion; stunted growth \\
& N. tabacum & Mild mosaic \\
241 & N. tabacum & Mild mosaic \\
\hline
\end{tabular}

the cooler winter months and milder during summer. There appeared to be a correlation between serogroup (Table 1) and severity of symptoms on Nicotiana species, tomato and capsicum, thus providing a means of distinguishing the CMV strains. The serogroup II strains (241 and 245) caused mostly mild mosaic in N. tabacum and N. glutinosa, whereas the serogroup I strains $(207,237,242,243$, and Twa) caused very severe mosaic often with blisters and leaf distortion in all Nicotiana species tested (Fig. 2a). CMV 242 and 243 were the only strains that caused moderately and severely deformed spindle leaves, respectively, in tomato (Fig. 2c). Serogroup I strains caused severe mosaic in capsicum, similar to the symptoms in Nicotiana species, with leaf distortion in the case of CMV 207 and 243. Serogroup II strains caused mild chlorotic spots and mosaic (Fig. 2b). CMV 243 was the most severe strain of all those tested on tomato, capsicum and $N$. glutinosa. It induced deformed spindle leaves in tomato and small leaves in capsicum, and stunted growth and curly deformed top leaves in $N$. glutinosa. Symptoms of CMV infection in cucurbit species did not reliably differentiate between the Australian strains. Symptoms in cucumber were generally mild and ranged from vein clearing and mottle to mild mosaic, whereas in zucchini, symptoms ranged from chlorotic spots and vein clearing to severe mosaic and reduced leaf size for all strains, depending on environmental conditions. Sweet corn was systemically infected by only two subgroup I strains, 207 and 237, which caused chlorotic streaks and spots along the leaf margins. CMV 245 caused chlorotic local lesions only on the inoculated maize leaves. The presence of CMV in symptomatic tissues and its absence in symptomless plants was confirmed by ELISA (data not shown). All strains, except Twa, were inoculated on bean and cowpea plants. All strains tested induced small, red, local lesions on inoculated cowpea leaves, and all, except CMV 243, induced a hypersensitive response in bean, characterised by small, white, local lesions on the inoculated leaves.
RNA 3 sequence variation and phylogeny

The sizes of RNA 3, 3a and CP open reading frames (ORF) and the intergenic regions between the $3 \mathrm{a}$ and $\mathrm{CP}$ genes of all eight Australian CMV strains are shown in Table 2. RNAs 3 of all CMV strains were about 2200 nucleotides in length, with minor size variations mostly in the non-coding regions. Interestingly, the ORF $3 \mathrm{a}$ of CMV 243 was three nucleotides shorter than that of the other strains (Table 2). When the ORF 3a sequences were aligned, a missing codon in the sequence of strain 243 was identified at positions 750-752. This deletion appeared to be specific to subgroup IB strain 243, because it did not occur in any other strain analysed, including the other subgroup IB strains Ix and Nt9.

When comparing the RNA 3 nucleotide sequences of the eight Australian CMV strains by pair-wise similarity analysis, two subgroups were evident, the sequences of which differed by about $28 \%$ (Table 4 ). The level of sequence identity within the two groups was at least $90 \%$. Within subgroup I, four strains had $96-99 \%$ nucleotide sequence identity to one another, but were only $90 \%$ identical to the nucleotide sequence of CMV 243. Q-CMV and Ly-CMV are members of subgroup II (Davies and Symons 1988; Roossinck 2002) and were closely related to strain 241 , which can also be classified as belonging to this subgroup. The other closely related CMV strains were classified as members of subgroup IA (CMV 207, 237, 242 and Twa) and IB (CMV 243).

Phylogenetic estimation of entire RNA 3 alignments was done to infer the relationship between the eight Australian CMV strains in the context of other CMV strains worldwide (Fig. 3). The maximum-parsimony tree of RNA 3 using a heuristic search showed three major clades representing subgroups IA, IB and II (Fig. 3). Subgroups IA and IB fell into completely separate clades. A more rigorous branchand-bound analysis using 18 taxa (data not shown) verified the validity of the heuristic search with all 21 taxa. Three of the Australian subgroup IA strains (237, 242 and Twa) 

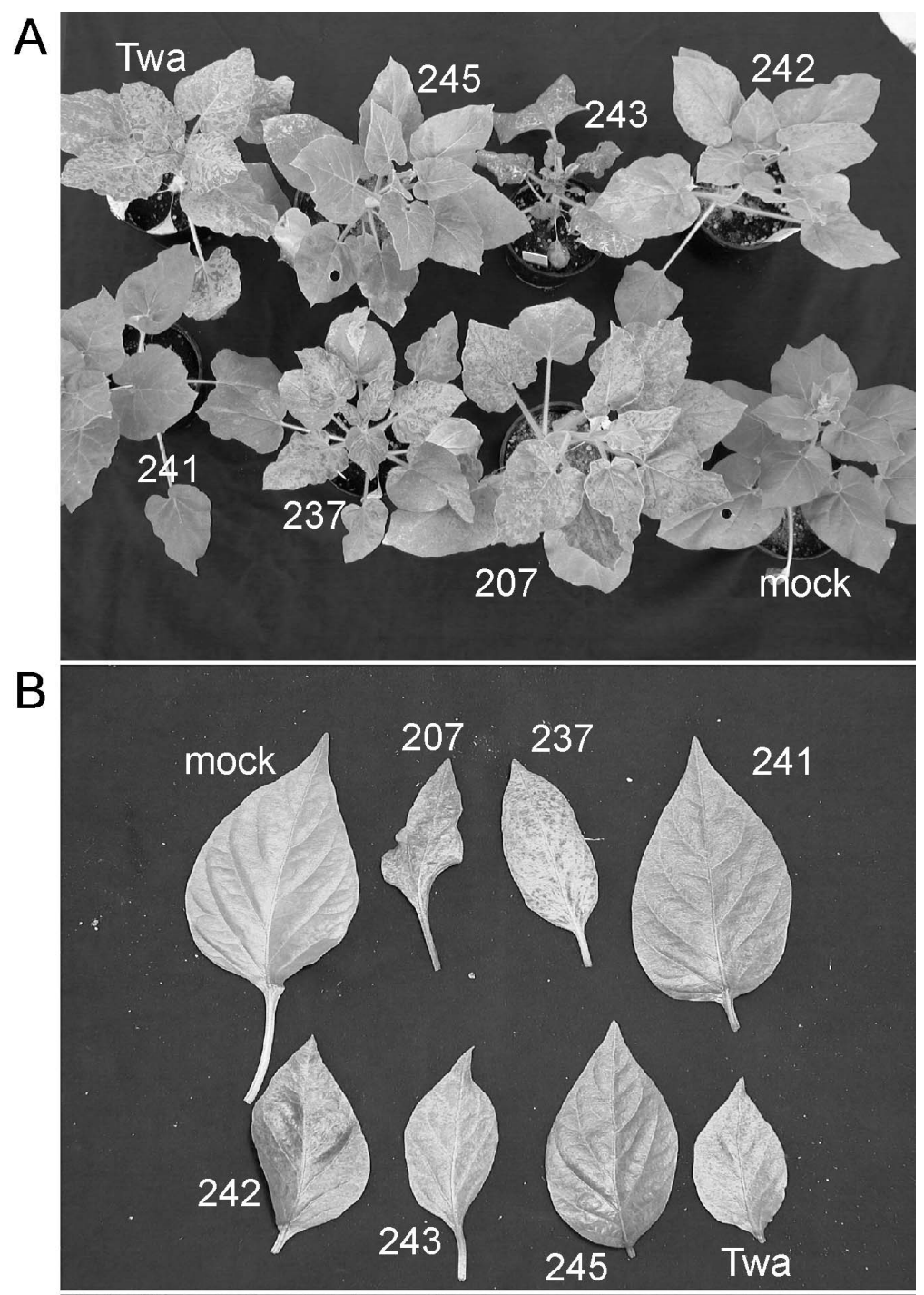

C

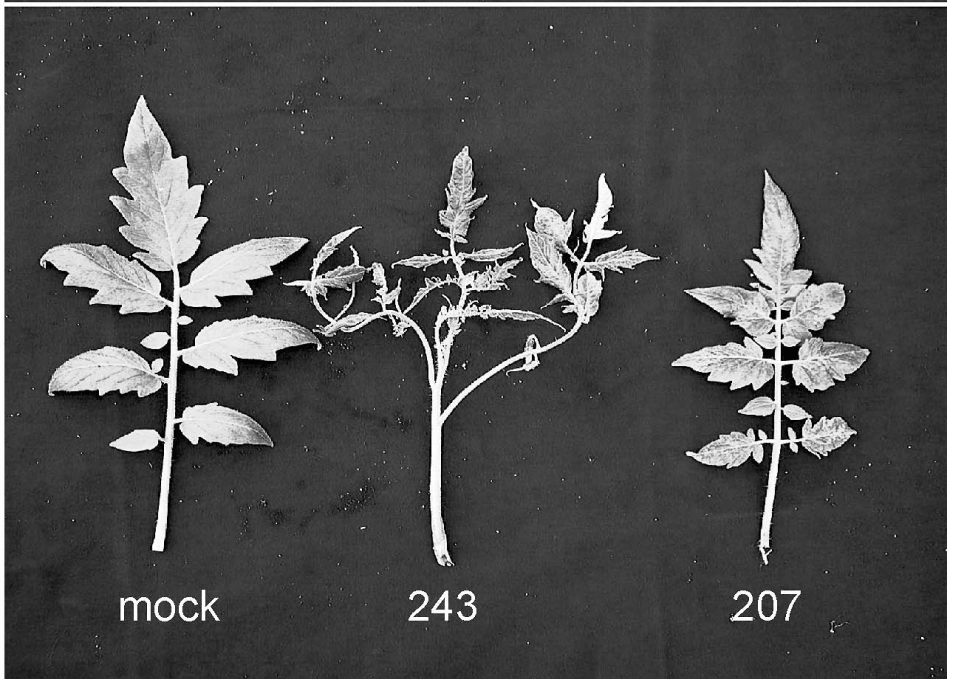

Fig. 2. Disease symptoms caused by Australian Cucumber mosaic virus strains on $(A)$ Nicotiana glutinosa plants, $(B)$ capsicum and $(C)$ tomato leaves, detached from infected plants 3 weeks post-inoculation. 


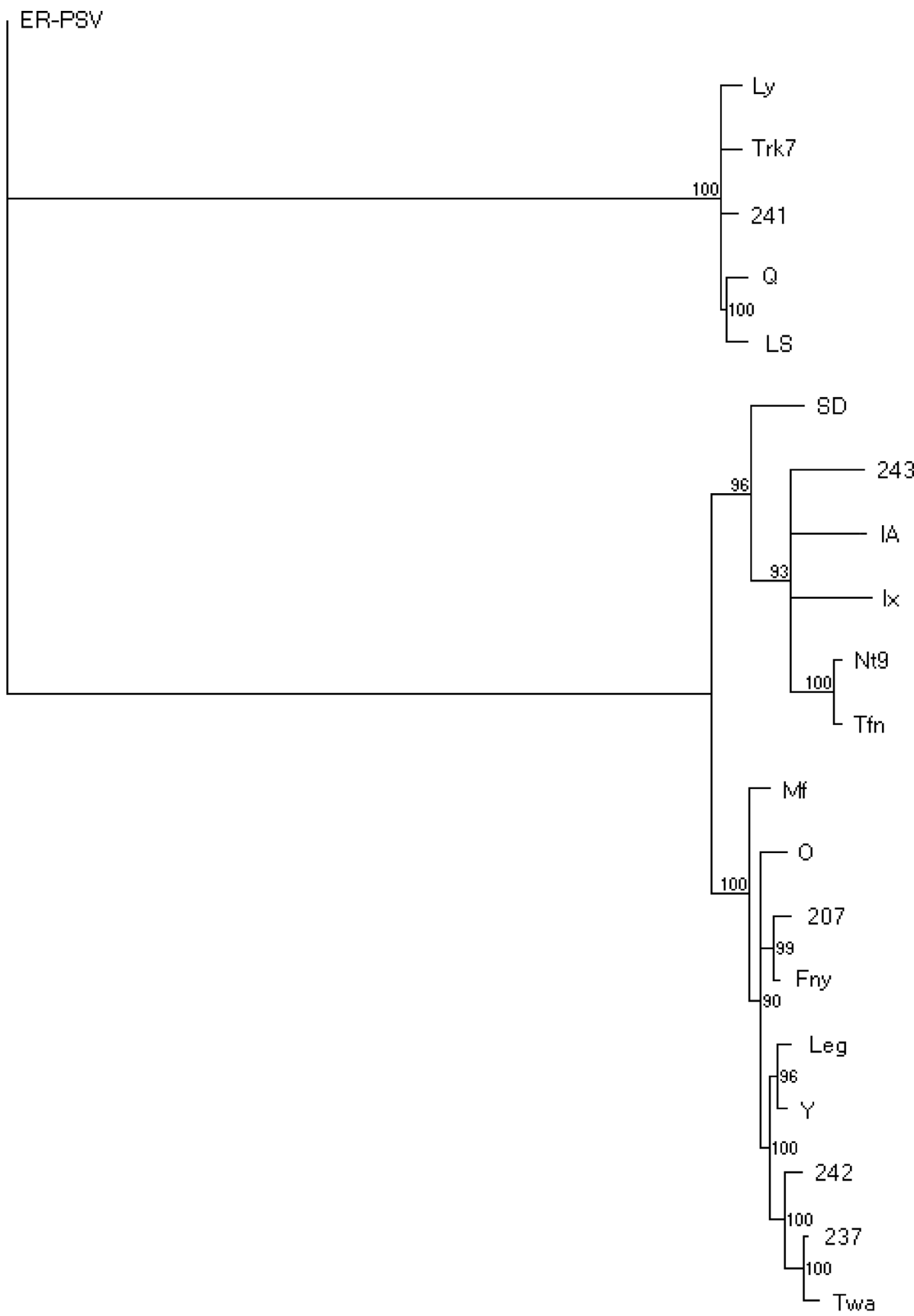

Fig. 3. Maximum-parsimony tree of full length RNA 3 sequences following a heuristic search of 21 Australian and reference Cucumber mosaic virus strains generated by PAUP analysis with 1000 bootstrap replicates. Horizontal branch length is proportional to genetic distance. The scale bar represents $5 \%$ divergence. Bootstrap values (\%) are shown above the branch points. 
Table 4. Nucleotide sequence identities (\%) between RNAs 3 of Australian Cucumber mosaic virus strains ${ }^{\mathrm{A}}$

\begin{tabular}{cccccccc}
\hline $\mathbf{2 3 7}$ & $\mathbf{2 4 2}$ & $\mathbf{T}_{\text {wa }}$ & $\mathbf{2 4 3}$ & $\mathbf{2 4 1}$ & $\boldsymbol{Q}$ & $\boldsymbol{L y}$ & \\
\hline 96.4 & 96.1 & 96.1 & 90.0 & 71.2 & 71.7 & 71.4 & $\mathbf{2 0 7}$ \\
& 97.5 & 98.9 & 90.2 & 72.3 & 72.2 & 71.9 & $\mathbf{2 3 7}$ \\
& & 97.0 & 90.1 & 72.2 & 72.2 & 72.0 & $\mathbf{2 4 2}$ \\
& & & 89.8 & 72.1 & 72.1 & 71.7 & $\mathbf{T}_{\text {wa }}$ \\
& & & & 72.0 & 71.7 & 71.6 & $\mathbf{2 4 3}$ \\
& & & & & 97.9 & 97.7 & $\mathbf{2 4 1}$ \\
& & & & & & 98.0 & $\boldsymbol{Q}$ \\
\hline
\end{tabular}

${ }^{\mathrm{A}}$ Subgroup II strains are shown in italics.

formed a tight cluster of closely related sequences, whereas CMV 207 was closely related to the USA strain Fny. All eight strains investigated could be assigned with confidence to the CMV subgroups as follows: strains 207, 237, 242 and Twa to subgroup IA, strain 243 to subgroup IB, and CMV 241, Ly and Q to subgroup II. Strain 243 appears to be the first IB strain reported in Australia. The groupings of CMV strains in the phylogenetic tree correlated with those identified by sequence similarity analysis, serology and symptomatology.

\section{Discussion}

The host range of CMV is exceptionally wide, exceeding 1200 species of monocots and dicots (Edwardson and Christie 1991). CMV occurs as hundreds of strains that cause a variety of disease symptoms. We have analysed six Australian CMV strains, which had only been minimally characterised and CMV 245, from which the fully sequenced Q-CMV (Davies and Symons 1988) is derived, with the aim to characterise their experimental host range and entire RNA 3. All strains were shown to be free from satellite RNA. Each strain could be differentiated by the symptom responses in Nicotiana species, capsicum and tomato, and the ability to systemically infect sweet corn. N. tabacum cv. Xanthi, N. edwardsonii and $C$. frutescens had previously been identified as useful host species on which Australian CMV strains of the two main subgroups could be differentiated (Wahyuni et al. 1992).

The different severity of symptoms induced by the CMV strains in the three Nicotiana species used here (Table 3, Fig. 2a) could be used to differentiate subgroup I strains (severe symptoms) from subgroup II strains (mild symptoms), similar to the observations of CMV strains systemically infecting tobacco (Zhang et al. 1994). Using pseudorecombinants, these authors concluded that CMV RNAs 1 and 2 were involved in determining symptom severity. On the other hand, Sugiyama et al. (2000) and Suzuki et al. (1995) reported that the severity of systemic mosaic symptoms in tobacco was controlled by amino acids 111 , 124 and 129 of the CMV CP gene on RNA 3. The unusual severe stunting and leaf blistering of $N$. glutinosa, but not other Nicotiana species by R-CMV was mapped to amino acid position 193 of the CP gene (Carrère et al. 1999; Szilassy et al. 1999).
Similar to the varied severity of CMV symptoms observed in tobacco, subgroup I strains generally caused mosaic and leaf deformation in capsicum, whereas symptoms caused by subgroup II strains were milder. Symptoms of subgroup IB strain 243 were more severe than those of subgroup IA strains, similar to what was observed for strains Fny (subgroup IA) and $\mathrm{K}$ (subgroup IB) previously (Hellwald et al. 2000a).

All Australian CMV strains infected tomato, but the symptoms varied considerably and as in other solanaceous hosts, subgroup I strains generally produced more severe symptoms compared to subgroup II strains. CMV 243 represents the first subgroup IB strain to be identified in Australia. It caused severe filiform leaves in tomato, similar to those induced by another subgroup IB strain, NT (Hellwald et al. 2000b) and by subgroup I strain KC119 (Stamova and Chetelat 2000) on susceptible tomato cultivars. Virulence in tomato has been attributed to both CMV RNAs 2 and 3 (Hsu et al. 1988; Hellwald et al. 2000b). All three strains originated from hot-temperate zones in northern Australia, the Philippines and China, respectively. Subgroup IB CMV strains are believed to occur mostly in Asia (Roossinck et al. 1999), but members of this subgroup have also been reported from the Pacific rim and from Hawaii (Roossinck et al. 1999) and California (Lin et al. 2003). The Tfn strain isolated in Italy likely originated in Asia (Roossinck 2002).

Sweet corn supported only replication and systemic movement of two of the CMV strains tested, 207 and 237, which belong to subgroup IA. Symptoms were similar to the systemic white mosaic reported for another subgroup IA strain I17E (Carrère et al. 1999). CMV 245 caused chlorotic lesions on inoculated leaves of sweet corn but did not move systemically. Local necrotic lesions on maize were determined by the $5^{\prime}$ portion of RNA 3 of the subgroup II R-CMV (Carrère et al. 1999). Previously, Wahyuni et al. (1992) reported that two Australian CMV subgroup I strains and Fny-CMV and one of nine Australian subgroup II strains tested induced chlorotic mosaic, leaf distortion and severe stunting of maize. The host range determinants required for infection of maize by subgroup IA Fny-CMV have been mapped to amino acid positions 129 (proline) and 162 (alanine) of the viral CP gene on RNA 3 (Ryu et al. 1998). Strains 207 and 237 have these same amino acids in those positions of the CP, but so do the other subgroup I strains Twa and 242, which do not infect sweet corn. This suggests that these host range determinants are necessary but may not be sufficient to overcome resistance to CMV in sweet corn.

We have used sequence variation within RNA 3 to estimate the evolutionary relatedness of the Australian CMV strains to published CMV strains from other geographic regions and representing the three subgroups. Interestingly, full length RNA 3 analysis placed subgroup IA and IB strains into separate clades, whereas in the phylogenies of 
RNA 3 ORFs (CP and 3a) IA strains cluster as a subclade within the IB strains (Roossinck 2002). This is similar to what is seen with phylogeny of RNA 2 ORFs (Roossinck 2002). Most likely this difference is due to the inclusion of the $5^{\prime}$ NTR, which shows subgroup-specific rearrangements that originally distinguished the two subgroups (Roossinck et al. 1999).

\section{Acknowledgements}

We thank J. E. Thomas and J. W. Randles for provision of CMV strains and advice, and J. E. Thomas for a critical reading of the manuscript. This research was supported by the Cooperative Research Centre for Tropical Plant Protection. E. Sulistyowati was supported by a PhD Scholarship from AusAID.

\section{References}

Carrère I, Tepfer M, Jacquemond M (1999) Recombinants of cucumber mosaic virus (CMV): determinants of host range and symptomatology. Archives of Virology 144, 365-379. doi: $10.1007 / \mathrm{S} 007050050510$

Clark MF, Adams AN (1977) Characteristics of the microplate method of enzyme-linked immunosorbent assay for the detection of plant viruses. The Journal of General Virology 34, 475-483.

Davies C, Symons RH (1988) Further implications for the evolutionary relationships between tripartite plant viruses based on cucumber mosaic virus RNA 3. Virology 165, 216-224. doi: 10.1016/00426822(88)90675-7

Ding S-W, Anderson BJ, Haase HR, Symons RH (1994) New overlapping gene encoded by the cucumber mosaic virus genome. Virology 198, 593-601. doi: 10.1006/VIRO.1994.1071

Edwardson JR, Christie RG (1991) Cucumoviruses. In 'CRC handbook of viruses infecting legumes'. pp. 293-319. (CRC Press: Boca Raton, FL).

Hellwald K-H, Glenewinkel D, Hauber S (2000a) Increased symptom severity in pepper plants after co-inoculation with two Cucumber mosaic virus subgroup I strains in comparison to single inoculations of the corresponding wildtype strains. Journal of Plant Diseases and Protection 107, 368-375.

Hellwald K-H, Zimmermann C, Buchenauer H (2000b) RNA 2 of cucumber mosaic virus subgroup I strain NT-CMV is involved in the induction of severe symptoms in tomato. European Journal of Plant Pathology 106, 95-99. doi: 10.1023/A:1008744114648

Hsu Y-H, Hu C-C, Lin N-S, Chiu R-J (1988) Symptom determinant of two Taiwan strains of cucumber mosaic virus is on RNA3. Botanical Bulletin Academia Sinica 29, 231-237.

Lin HX, Rubio L, Smythe A, Jiminez M, Falk BW (2003) Genetic diversity and biological variation among California strains of Cucumber mosaic virus. The Journal of General Virology 84, 249-258. doi: 10.1099/VIR.0.18673-0

Palukaitis P, Roossinck MJ, Dietzgen RG, Francki RIB (1992) Cucumber mosaic virus. Advances in Virus Research 41, 281-348.

Pares RD, Dietzgen RG, Gunn LV, Rizos H (1998) Differentiation of Australian cucumber mosaic virus strains: comparison of dsRNA type, polymerase chain reaction-restriction enzyme analysis, DNA hybridisation and serogrouping. Australasian Plant Pathology 27, 36-39.

Rezaian MA, Williams RH, Gordon KH, Gould AR, Symons RH (1984) Nucleotide sequence of cucumber mosaic virus RNA 2 reveals a translation product significantly homologous to corresponding proteins of other viruses. European Journal of Biochemistry 143, 277-284.

Rezaian MA, Williams RH, Symons RH (1985) Nucleotide sequence of cucumber mosaic virus RNA 1. Presence of a sequence complementary to part of the viral satellite RNA and homologies with other viral RNAs. European Journal of Biochemistry 150, 331-339.

Roossinck MJ (2002) Evolutionary history of Cucumber mosaic virus deducted by phylogenetic analyses. Journal of Virology 76, 3382-3387. doi: 10.1128/JVI.76.7.3382-3387.2002

Roossinck MJ, Palukaitis P (1990) Rapid induction and severity of symptoms in zucchini squash (Cucurbita pepo) map to RNA 1 of cucumber mosaic virus. Molecular Plant-Microbe Interactions $\mathbf{3}$, $188-192$.

Roosinck MJ, White PS (1998) Cucumovirus isolation and RNA extraction. In 'Methods in molecular biology. Vol. 81. Plant virology protocols: from virus isolation to transgenic resistance'. (Eds GD Foster, SC Taylor) pp. 189-196. (Humana Press Inc.: Totowa, $\mathrm{NJ}$ )

Roossinck MJ, Zhang L, Hellwald K-H (1999) Rearrangements in the $5^{\prime}$ nontranslated region and phylogenetic analyses of cucumber mosaic virus RNA 3 indicate radial evolution of three subgroups. Journal of Virology 73, 6752-6758.

Ryu KH, Kim C-H, Palukaitis P (1998) The coat protein of Cucumber mosaic virus is a host determinant for infection of maize. Molecular Plant-Microbe Interactions 11, 351-357.

Soards AJ, Murphy AM, Palukaitis P, Carr JP (2002) Virulence and differential local and systemic spread of Cucumber mosaic virus in tobacco are affected by the CMV $2 \mathrm{~b}$ protein. Molecular Plant-Microbe Interactions 15, 647-653.

Stamova BS, Chetelat RT (2000) Inheritance and genetic mapping of Cucumber mosaic virus resistance introgressed from Lycopersicon chilense into tomato. Theoretical and Applied Genetics 101, 527-537. doi: 10.1007/S001220051512

Sugiyama M, Sato H, Karasawa A, Hase S, Takahashi H, Ehara Y (2000) Characterization of symptom determinants in two mutants of cucumber mosaic virus $\mathrm{Y}$ strain, causing distinct mild green mosaic symptoms in tobacco. Physiological and Molecular Plant Pathology 56, 85-90. doi: 10.1006/PMPP.1999.0250

Suzuki M, Kuwata S, Masuta C, Takanami Y (1995) Point mutations in the coat protein of cucumber mosaic virus affect symptom expression and virion accumulation in tobacco. The Journal of General Virology 76, 1791-1799.

Szilassy D, Salánki K, Balázs E (1999) Stunting induced by cucumber mosaic cucumovirus-infected Nicotiana glutinosa is determined by a single amino acid residue in the coat protein. Molecular Plant-Microbe Interactions 12, 1105-1113.

Thompson JD, Higgins DG, Gibson TJ (1994) ClustalW: improving the sensitivity of progressive multiple sequence alignment through sequence weighting, position-specific gap penalties and weight matrix choice. Nucleic Acids Research 22, 4673-4680.

Wahyuni WS, Dietzgen RG, Hanada K, Francki RIB (1992) Serological and biological variation between and within subgroup I and II strains of cucumber mosaic virus. Plant Pathology 41, 282-297.

Zhang L, Hanada K, Palukaitis P (1994) Mapping local and systemic symptom determinants of cucumber mosaic cucumovirus in tobacco. The Journal of General Virology 75, 3185-3191.

Received 11 February 2004, accepted 8 April 2004 